
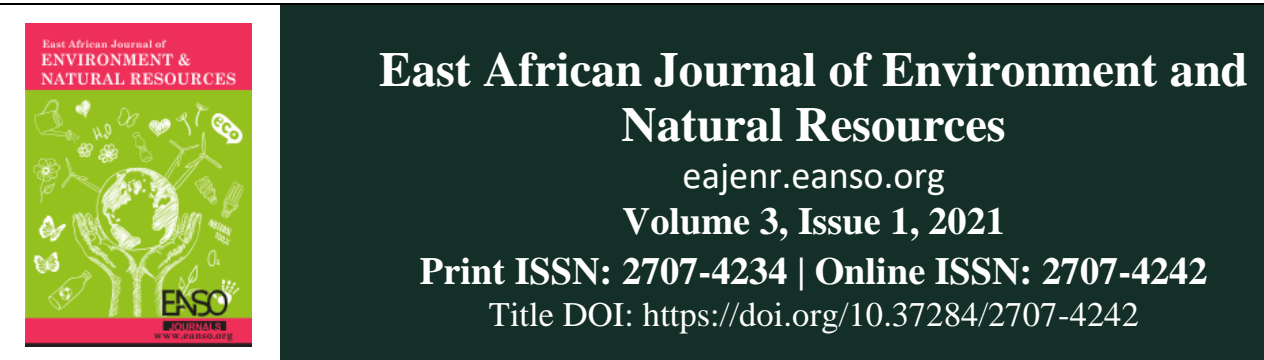

Original Article

\title{
Enhanced Shared Governance Improves the Collaborative Management of Protected Areas in Zimbabwe.
}

\author{
Geoffreys Matipano ${ }^{1 *}$ \& Reinford Khumalo, $P h D^{1}$ \\ ${ }^{1}$ Zimbabwe Open University, Harare, Zimbabwe \& Parks and Wildlife Management Authority, P. O. Box CY 140, Causeway, \\ Harare, Zimbabwe. \\ *Correspondence email: gmatipano@yahoo.com.
}

Article DOI: https://doi.org/10.37284/eajenr.3.1.378

\section{Date Published: ABSTRACT}

05 August 2021 A majority of protected areas are not being managed effectively enough to ensure the perpetuity of biological resources they contain due to impediments such as poor

Keywords: governance. This study focused on the experiences in the shared governance of

people involved in partnership-managed protected areas and also on developing

Shared critical success factors in implementing such partnerships. The interpretivism

Governance, approach was appropriate for this qualitative, inductive, descriptive, and

Collaboration exploratory three-case study that used in-depth interviews and open-ended quester-

Management, views with a purposive sample to generate data. In the early stages of the projects,

Protected Area, the protected area shared governance was not stable and was characterized by many

Critical Success pitfalls because the concept of partnerships was new in Zimbabwe. It is important

Factors. to develop guiding frameworks and build capacity that eliminates governance vacuum, ambiguity, deficiencies, overcrowding, redundancies, bureaucracy, and politics from the early stages of the partnerships. Community participation is crucial in the management and long-term sustainability of protected areas in developing countries. Further, governance reforms for the protected areas needed to recognize traditional and cultural sites in the project areas and develop governance types of the sacred sites formally attributed to the local ethnic indigenous people nested within project shared governance. Some critical success factors of well-shared governance of protected areas are in the text. However, all the principles of good governance may not be usable in one case study

\section{APA CITATION}

Matipano, G. \& Khumalo, R. (2021). Enhanced Shared Governance Improves the Collaborative Management of Protected Areas in Zimbabwe. East African Journal of Environment and Natural Resources, 3(1), 91-107. https://doi.org/10.37284/eajenr .3.1.378

91 | This work is licensed under a Creative Commons Attribution 4.0 International License. 


\section{CHICAGO CITATION}

Matipano, Geoffreys \& Reinford Khumalo. 2021. "Enhanced Shared Governance Improves the Collaborative Management of Protected Areas in Zimbabwe". East African Journal of Environment and Natural Resources 3 (1), 91-107. https://doi.org/10.37284/eajenr.3.1.378.

\section{HARVARD CITATION}

Matipano, G. Khumalo, R. (2021) "Enhanced Shared Governance Improves the Collaborative Management of Protected Areas in Zimbabwe", East African Journal of Environment and Natural Resources, 3(1), pp. 91-107. doi: 10.37284/eajenr.3.1.378.

\section{IEEE CITATION}

G. Matipano R. Khumalo, "Enhanced Shared Governance Improves the Collaborative Management of Protected Areas in Zimbabwe", EAJENR, vol. 3, no. 1, pp. 91-107, Aug 2021.

\section{MLA CITATION}

Matipano, Geoffreys \& Reinford Khumalo. "Enhanced Shared Governance Improves the Collaborative Management of Protected Areas in Zimbabwe". East African Journal of Environment and Natural Resources, Vol. 3, no. 1, Aug 2021, pp. $91-$ 107, doi:10.37284/eajenr.3.1.378.

\section{INTRODUCTION}

The International Union for Conservation of Nature (IUCN) defines a protected area as "a clearly defined geographical space, recognized, dedicated and managed, through legal or other effective means, to achieve the long-term conservation of nature with associated ecosystem services and cultural values" (Borrini-Feyerabend et al., 2013, p. 5). In Zimbabwe, legally gazetted protected conservation areas cover about $12.5 \%$ of the total land surface area of the country (Government of Zimbabwe, 1996) against a global target of $17 \%$ (Convention on Biological Diversity, 2010).

Globally, a majority of protected areas are not being managed effectively enough to ensure the perpetuity of biological resources they contain (McNeely, 1988) due to many impediments including poor governance (Borrini-Feyerabend et al., 2013).

\section{Wildlife Conservancy: Other Effective Means}

Conservancies that were a unilateral undertaking on the part of the member ranchershad no statutory definition in Zimbabwe and their internal constitution governed members, e. g. Save Valley Conservancy (Wolmer et al., 2004, p. 11). Before the land reform programme, participation in the conservancies was not broad-based. The government suspected that conservancies were an attempt by large-scale farmers to privatize wildlife to challenge the State's control over wildlife and exclude local communities from exploiting the wildlife resource (Wolmer et al., 2004, p. 4).
Community participation is a crucial success factor in the management and long-term sustainability of private conservancies in Zimbabwe (African Wildlife Foundation, 2012). Indigenization of the wildlife industry without substantial community participation will leave those communities marginalized and likely to continue poaching and engage in other forms of resource degradation, thereby making the conservancy unsustainable (AWF, 2012).

\section{Partnership for Management of Protected Areas}

Globally, partnerships are increasingly becoming an essential strategy in managing protected areas (Yang, 2011; Stolton \& Dudley, 2014; Hatchwell, 2014). Outside Africa, partnership management of protected areas exists in many countries, including Brazil, Chile (Becker, 2016) and Australia (Bauman \& Smyth, 2007).

In sub-Saharan Africa, public-private partnerships (PPPs) for protected areas exist in Malawi, Zambia, Democratic Republic of Congo, Rwanda, Central Africa Republic, Congo Republic, and Chad as well as Zimbabwe (African Parks, 2011, p. 1). Examples of private-community partnerships exist in the Western Serengeti Ecosystem, Tanzania (Emerton \& Mfunda, 1999) and South Africa (Reid et al., 2004). Zimbabwe's only three gazetted partnership managed protected areas were Gonarezhou National Pak (GNP) and Mufurudzi Safari Area (MSA) since 2008, and Matusadona National Park since March 2020 . 


\section{Protected Area Governance}

Governance is the interaction among structures, processes and traditions that determine how power and responsibilities are exercised, how decisions are taken and how citizens or other stakeholders have their say (Graham et al. 2003, p. 2), and it is about who defines the overall objectives and how, and the allocation of responsibility and accountability for delivering on these objectives (Worboys et al., 2018, p. 171). Partnerships involve shared governance. IUCN outlined five governance principles with forty considerations for protected areas (Borrini-Feyerabend et al. 2013), which were consolidated into eleven principles by (Franks et al., 2018). Given that partnerships for the management of protected areas are in their infancy in Zimbabwe, this study focused on finding out how those people directly working in or affected by partnershipmanaged protected areas think about the shared governance of the areas. Secondly, the study aimed at developing critical success factors for shared governance in conservation partnerships.

\section{MATERIALS AND METHODS}

\section{Description of Case Studies}

The research used three case studies, namely Gonarezhou National Park (GNP), Mufurudzi Safari area (MSA), and Save Valley Conservancy (SVC) (Figure 1).

Figure 1: Locations of Gonarezhou National Park, Mufurudzi Safari Area, and Save Valley Conservancy in Zimbabwe

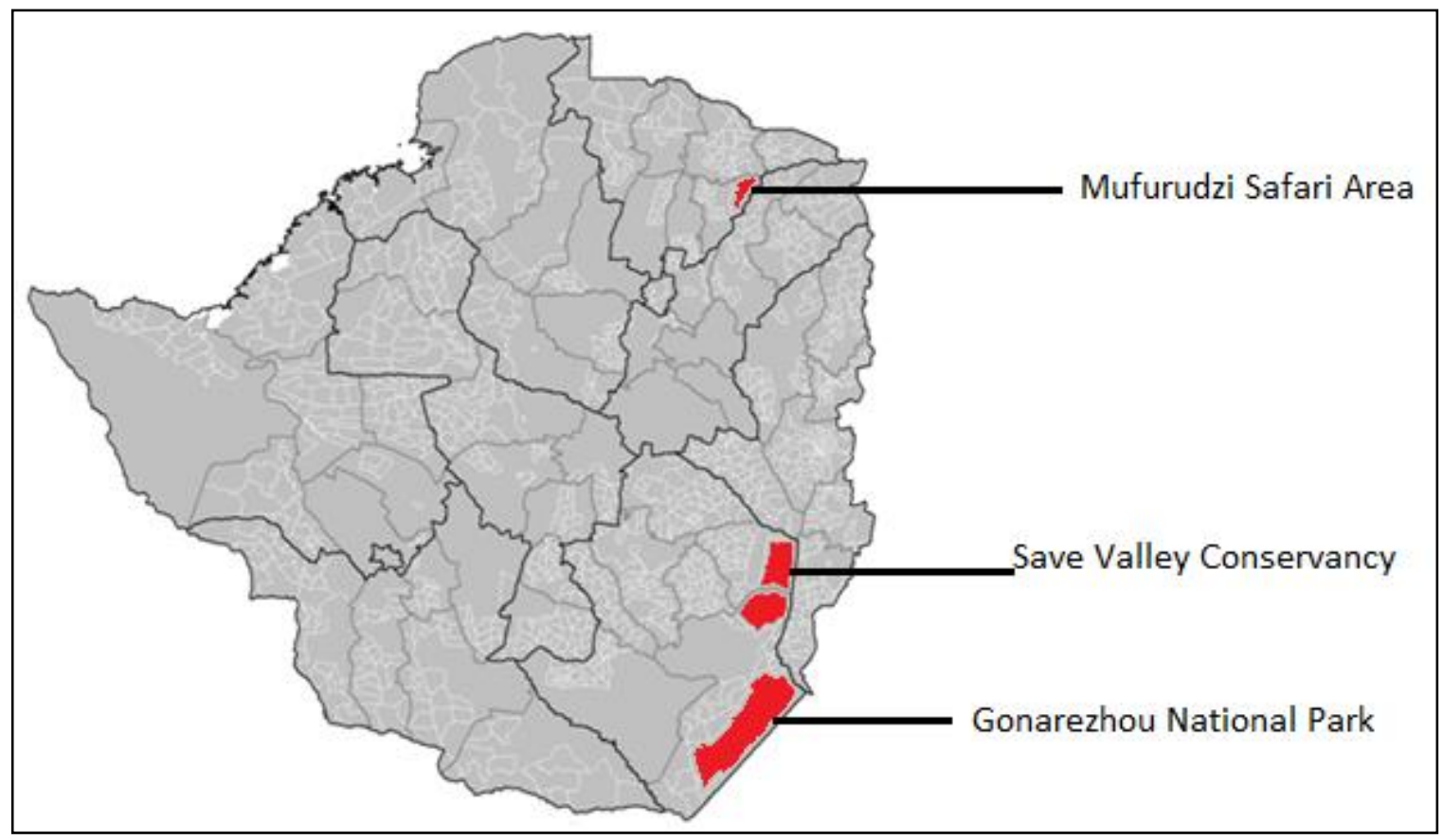

GNP project represented a public-private partnership (PPP) between a public entity, Zimbabwe Parks and Wildlife Management Authority (ZPWMA), and a not-for-profit, nongovernmental organization, Frankfurt Zoological Society (FZS). ZPWMA is a national wildlife management agency. The Park is $5053 \mathrm{~km}^{2}$ in area, located in Chiredzi District, Masvingo Province, in the south-eastern part of Zimbabwe. The Park excluded the surrounding Hlengwe people who lived in the adjacent communal lands. MSA project is a commercial PPP between ZPWMA and a profitoriented private company, Pioneer Travel and Tours (Pvt) Ltd (PTTPL). MSA, $760 \mathrm{~km}^{2}$ in area, is located in the Shamva district of Mashonaland East Province of Zimbabwe.

93 This work is licensed under a Creative Commons Attribution 4.0 International License. 
The project excluded the Shona-speaking people surrounding the safari area. SVC was a nascent community-oriented commercial partnership under negotiation by potential partners including local communities and public and private players. SVC initially had twenty-seven wildlife ranches, 3,442 $\mathrm{km}^{2}$ in size before the land reform programme was started in 2000. Both the Shona and Hlengwe communities surround the area.

GNP and MSA were single properties under the jurisdiction of ZPWMA. Originally SVC had a decentralized management system of individually managed twenty-five private wildlife farms and two other farms owned by government entities. The property owners came together in 1997 through a constitution to manage the conservancy. During the land reform programme from 2000 to 2020, the status of land occupation in SVC changed. Twentyfour farms were gazetted farms and became state property under the administration of the ZPWMA and eight of these were legally and illegally occupied by local people for subsistence agriculture. The former private owners of the other ten farms covered by bilateral investment protection and promotion agreements (BIPPAs) between Zimbabwe and other countries were allowed to stay and co-exist with eight-four new indigenous farmers holding 25-year leases issued by Government under the land reform programme. The new farmers were varying in numbers per given lease per property. The government spared three government and indigenous-owned farms from gazetting under the land reform programme. After the land reform programme, properties within the conservancy continued to be run under a decentralized management system of individually managed hunting and photographic concessions.

\section{Approach to the Research}

The interpretivism approach was appropriate for this qualitative research in which the subjective perceptions and meanings of the research participants are acceptable, and they defined the nature of reality (Saunders et al., 2009, p. 119). A three-case study was inductive, descriptive, and exploratory because the topic of shared governance in partnerships management of protected areas was new in Zimbabwe.
Purposive sampling produced a sample of research participants that can be logically assumed to be representative of the population (Lavrakas, 2008). The theoretical sampling technique used allowed the study to cover more than one protected area and it allowed the researchers to follow leads in the data by sampling new participants that provided relevant information (Tie et al., 2019). It also involved data generation whereby the researchers jointly collect, code, and analyse the data and decides on the following data to collect and where to locate the data (Tie et al., 2019). There was no proof of reaching theoretical saturation. Data from GNP and MSA were generally similar because the projects were at the implementation stage, and the researchers selected SVC that presented a peculiar data set about a partnership project in its formative phase involving local communities.

\section{Data Generation and Analysis}

The primary data generation technique supplemented by the questionnaires was used indepth interviews that lasted an average of 35 minutes (Range 25-65 minutes) per participant, where the primary research instrument was the researcher. The researchers upheld ethical considerations by respecting the rights and feelings of the people who were affected by the research. The researchers used triangulation, member checking, thick description of data, and prolonged engagement of participants in mitigating the researcher's effect or managing subjectivity and to achieve trustworthiness and credibility of data. The manual qualitative data analysis used an inductively based analytical strategy which has three concurrent sub-processes, data reduction, data displays and drawing, and verifying conclusions (Miles \& Huberman, 1994). The data was presented in the form of numerical frequencies of practical experiences into tables, diagrammatic or visual presentations of the case study governance structures.

\section{RESULTS}

\section{Profiles of the Research Participants}

There were 150 research participants $(79.9 \%$ male; $20.1 \%$ female $)$ in GNP $(\mathrm{n}=80)$, MSA $(\mathrm{n}=55)$ and SVC $(n=15)$ put in two groups. Group One (I) had 
people involved directly with the projects. The group had a total of 38 interview participants, i.e., GNP ( $n=14$ senior former and current officers), MSA ( $\mathrm{n}=9$ senior former and current officers) and SVC ( $\mathrm{n}=15$ composed of 3 senior former and current officers, 4 former farmers, 4 new farmers and 4 traditional chiefs). In the SVC project, out of the nine traditional chiefs, only four chiefs whose chiefdoms covered some parts of the conservancy participated in the interviews.

The other five chiefs neighbouring the conservancy were excluded from the project at one of the provincial meetings held on the project. All the research participants, except one senior female employee at the Mufurudzi project, were males. Group Two (II) had local communities that were not formally included in GNP and MSA projects. The group had a total of one hundred and twelve (112) research participants, i.e. GNP $(n=66)$ and MSA (n $=46$ ) projects underwent interviews. The leaders were made up of chiefs, headmen, village heads, serving and former members of parliament and councillors. The average number of women participants was $26.8 \%$ (i.e., $\mathrm{GNP}=25.8 \%$; $\mathrm{MSA}=$ $28.3 \%)$.

\section{Gonarezhou Governance Arrangements}

\section{Governance Arrangements between 2007 and February 2017}

The reconstruction of the governance arrangement for GNP before the formation of a Trust from 2007 to February 2017 is in Figure 2.

Figure 2: Governance arrangements of the GNP PPP: 2007-February 2017

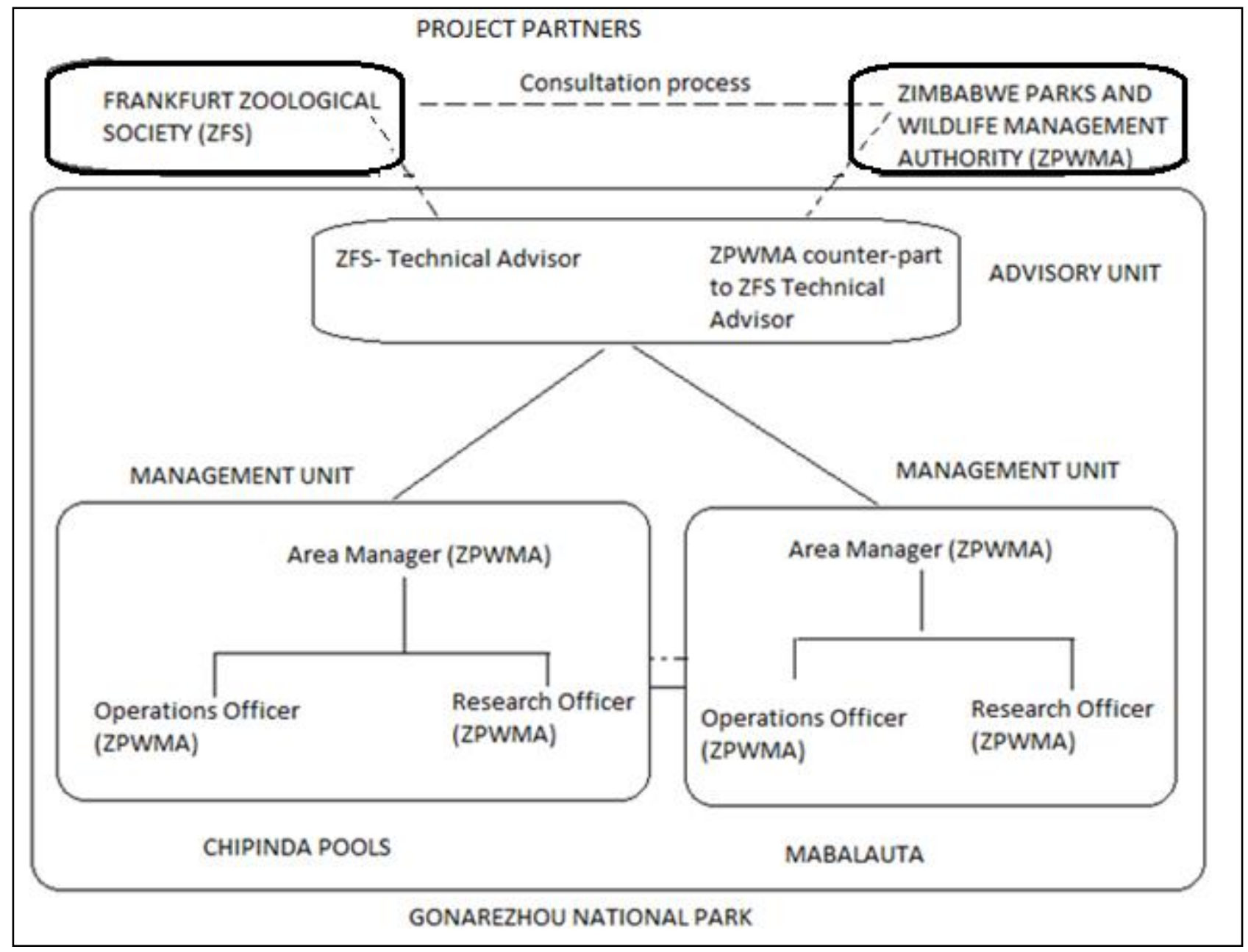

95 | This work is licensed under a Creative Commons Attribution 4.0 International License. 
Initially, GNP had two administrative sections, namely Chipinda and Mabaluta, each headed by an area manager. The Agreement had no provision for a decision-making board for the project but an advisory unit composed of one representative from either partner. ZPWMA never filled the post of counterpart to private partner technical advisor as required by the Memorandum of Agreement (MoA) signed between the partners. The partner parallel staff structures were using different human resources policies. The FZS technical advisor had no clear reporting lines as he could report to the station, FZS, ZPWMA, and Zimbabwe Ministry responsible for the management of protected areas. The General Management Plan for the area did not explicitly talk about partnership arrangements to manage the park. Although the project started in 2007, the agreement signing was in 2010, and thereafter the private partner was registered to operate in the country in 2011.

\section{Governance Arrangements from March 2017 onwards}

In June 2013, the GNP model was reviewed to increase funding towards biodiversity conservation and economic development of the parks. In turn, the Gonarezhou Conservation Trust (GCT) with a Board of Trustees was formed to oversee the management of GNP through the signing of a Trust Deed in March 2017. The Trust is an independent entity capable of suing and being sued in its name. The Board of Trustees consisted of three members seconded from either party. The Board of Trustees appointed a Trust Director Manager who reported directly to the Chairman of the Board of Trustees. The Chairmanship of the Board was on a rotational basis between the partners. Decision making was by unanimous agreement by the trustees, and the Chairman exercised a casting vote where there is a tie. The Board of Trustees would meet at least twice a year guided by the Ministerial approved Gonarezhou Management Plan and the annual board-approved action plans. The new structure of staffing in GNP consisted of two administrative units, i.e., Operational staff (ZPWMA employed and seconded to the Trust) and Support staff employed by the Trust (Figure 3).

Figure 3: Shared governance to improve the management of Gonarezhou National Park since March 2017

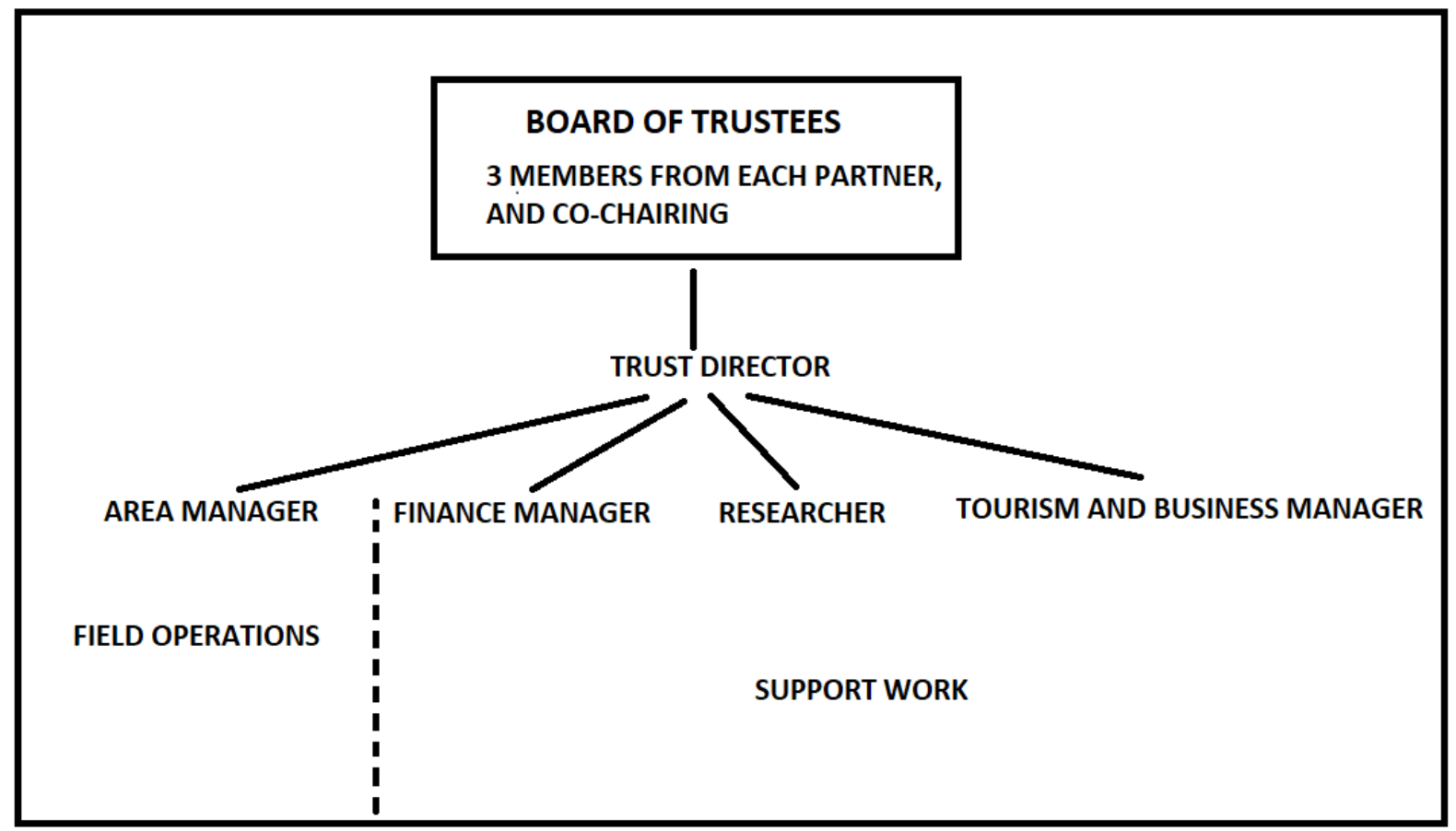

96 | This work is licensed under a Creative Commons Attribution 4.0 International License. 
The ZPWMA Area Manager seconded to the Trust, oversaw the general operations of the GNP, and reported to the Project Manager. The project director and his team were responsible for the management of the partnership project. The project's lifespan was 20 years and renewable for another 20 years on mutual agreement. ZPWMA would provide organizational level support, expertise, personnel, and board-level guidance. ZPWMA would be responsible for resolving any potential political disputes that may arise during the agreement. On the other hand, FZS would provide funding support to the Trust for GNP, organizational level support, expertise, personnel, and board-level guidance. Local communities were not formally included in GNP. The project should ensure a performance culture so that managers become accountable for their performance. Lastly, the park should retain all the revenue it generates.
Local communities continued to be alienated from the project.

\section{Mufurudzi Governance Arrangements}

\section{Governance Arrangements from 2007 and 2012}

In the initial stages, like GNP, the MSA governance arrangement had no provision for a decision-making board but only a Management Committee composed of two members from either Partner (Figure 4). ZPWMA officers in the Management Committee had no decision-making mandate and that left the private partner making most of the decisions and day-to-day management of the project. The partners tended to make unilateral decisions and had staff parallel structures that used different policies. The partners alternatively unilaterally hired the project manager to fill the vacant post. The independent chair was never recruited.

Figure 4: Shared Governance of the Mufurudzi Safari Area PPP project since 2013

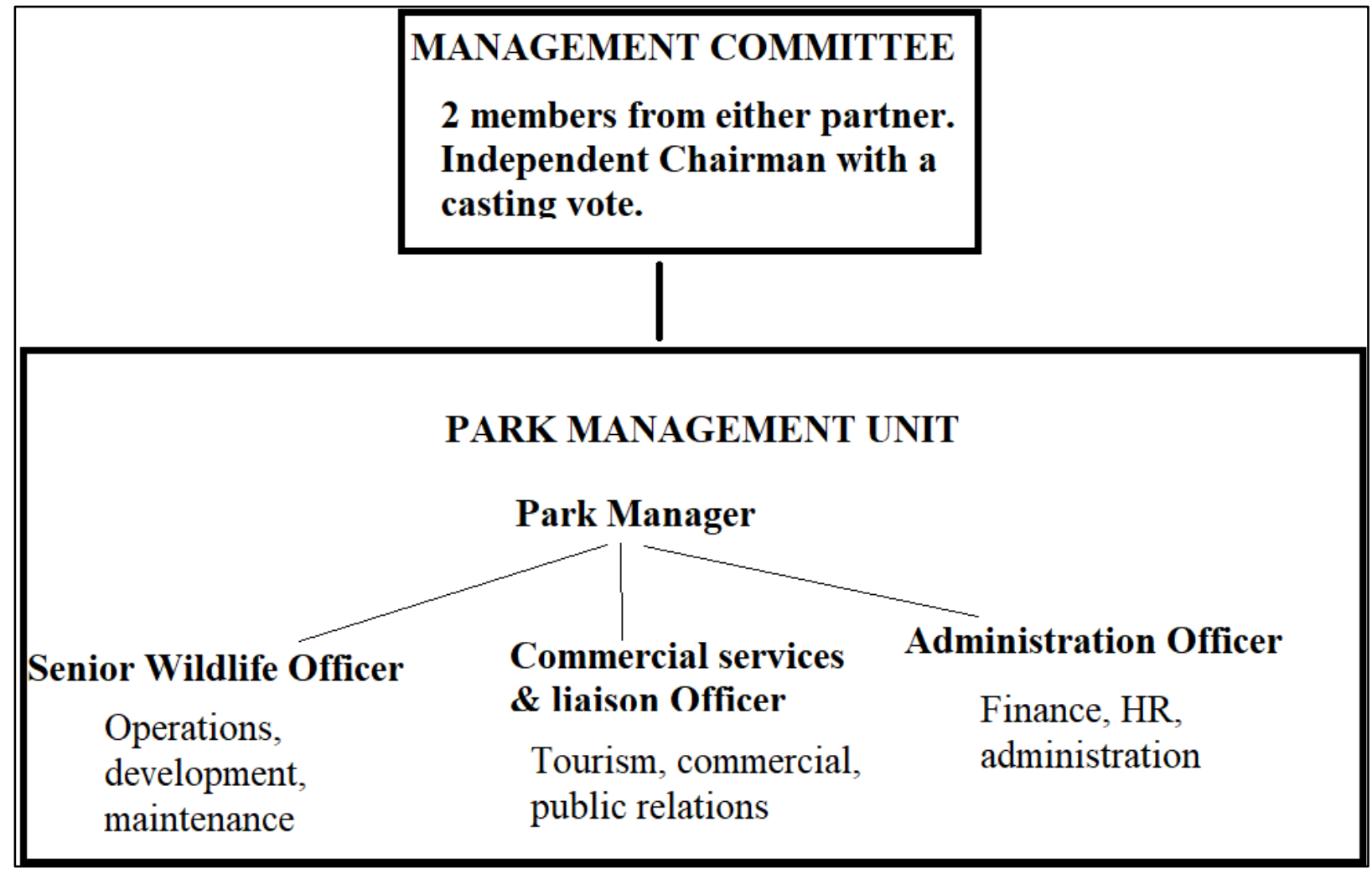

Governance Arrangements from 2013 Onwards

The Board of Directors was established in 2013 with equal representation, two members from either partner. The Partners chaired quarterly meetings on a rotational basis and the Chairman had a casting vote in the event of a split vote. A quorum for members was a minimum of three people. The

97 This work is licensed under a Creative Commons Attribution 4.0 International License. 
Management Committee was retained with a similar representation to the Board (Figure 5). A Park Manager was employed and reported to the Chairperson of the Board of Directors. The Management Committee employed the managerial team headed by a Park Manager. The Management Committee guided the project manager on the management of the project. In MSA, representatives of the private partner sitting on the board were also in the Management Committee. On the other hand, the public partner used to bring more people to the meetings than those stipulated in the Agreement. Local communities were not formally included in MSA.

Figure 5: Shared governance to improve the collaborative management of Mufurudzi Safari Area after 2013

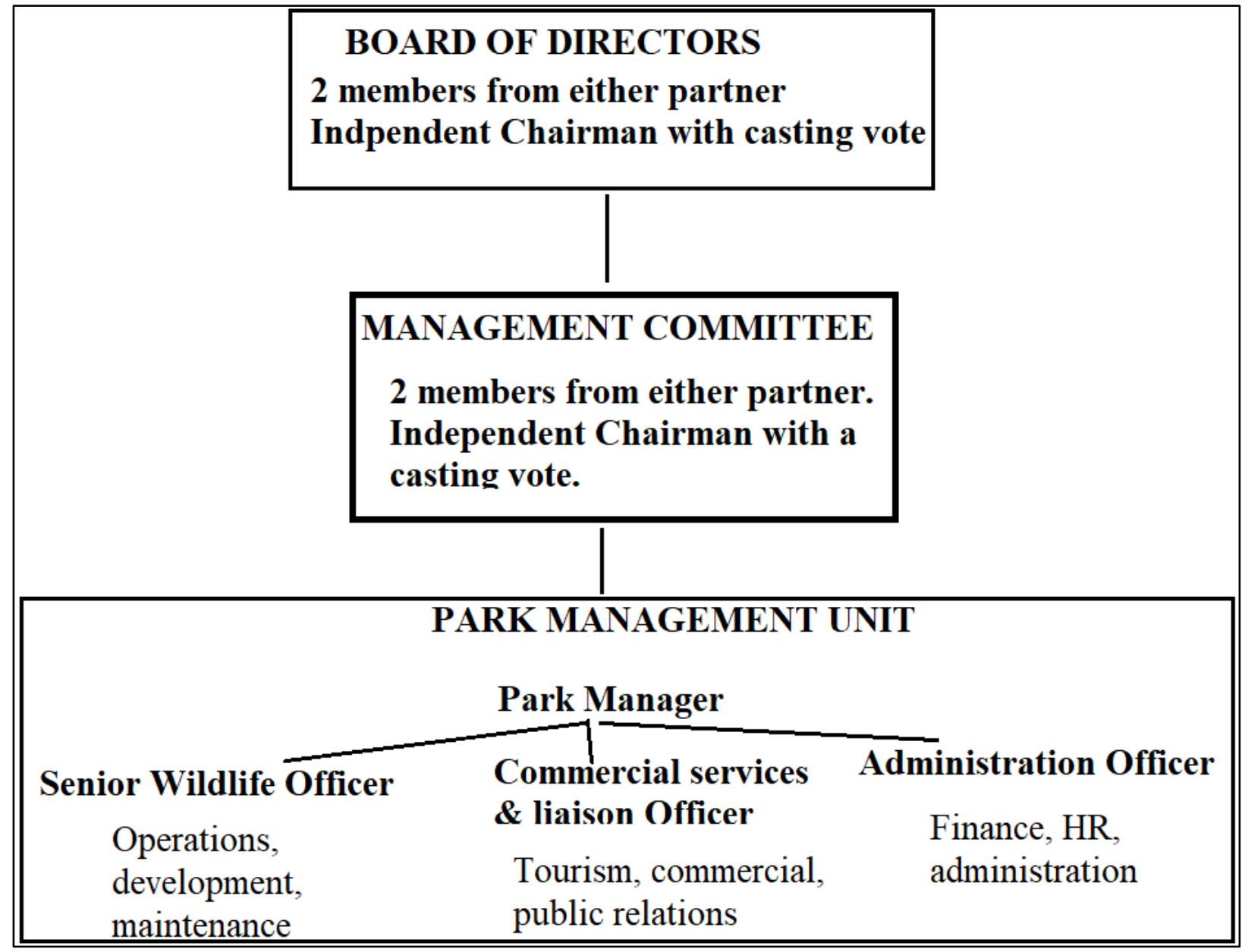

\section{Governance of Save Valley Conservancy}

Governance Arrangements from 2007 to 2014

After the land reform programme, twenty-four properties except three owned by an indigenous farmer, local authority (Bikita Rural District Council), and a government parastatal were placed under the administration of ZPWMA in 2007. A group of new farmers was allocated the gazetted farms through a twenty-five-year lease. The former farmers had an option to remain and jointly work with the new farmers on the gazetted farms. According to the Wildlife Based Land Reform Policy, the new and former farmers were supposed to work with the local communities, while ZPWMA was an advisor in the public-private-community partnership (PPCP). Local communities first became a legally identifiable entity, a Trust, through a legal process, having a Deed of Trust for SVC communities and their Chiefs. ZPWMA, established through an Act of Parliament, the Parks 
and Wildlife Act Chapter 20:14, represented Government as an advisor. Private former and new farmers would remain bound together through a constitution (with an option to form a company). All the partners were supposed to enter into the PCP through another legal process of a Memorandum of Understanding or Agreement (MOA) and form a Board (Figure 6).

Figure 6: Governance structures of the SVC Private-Community Partnership project since 2016

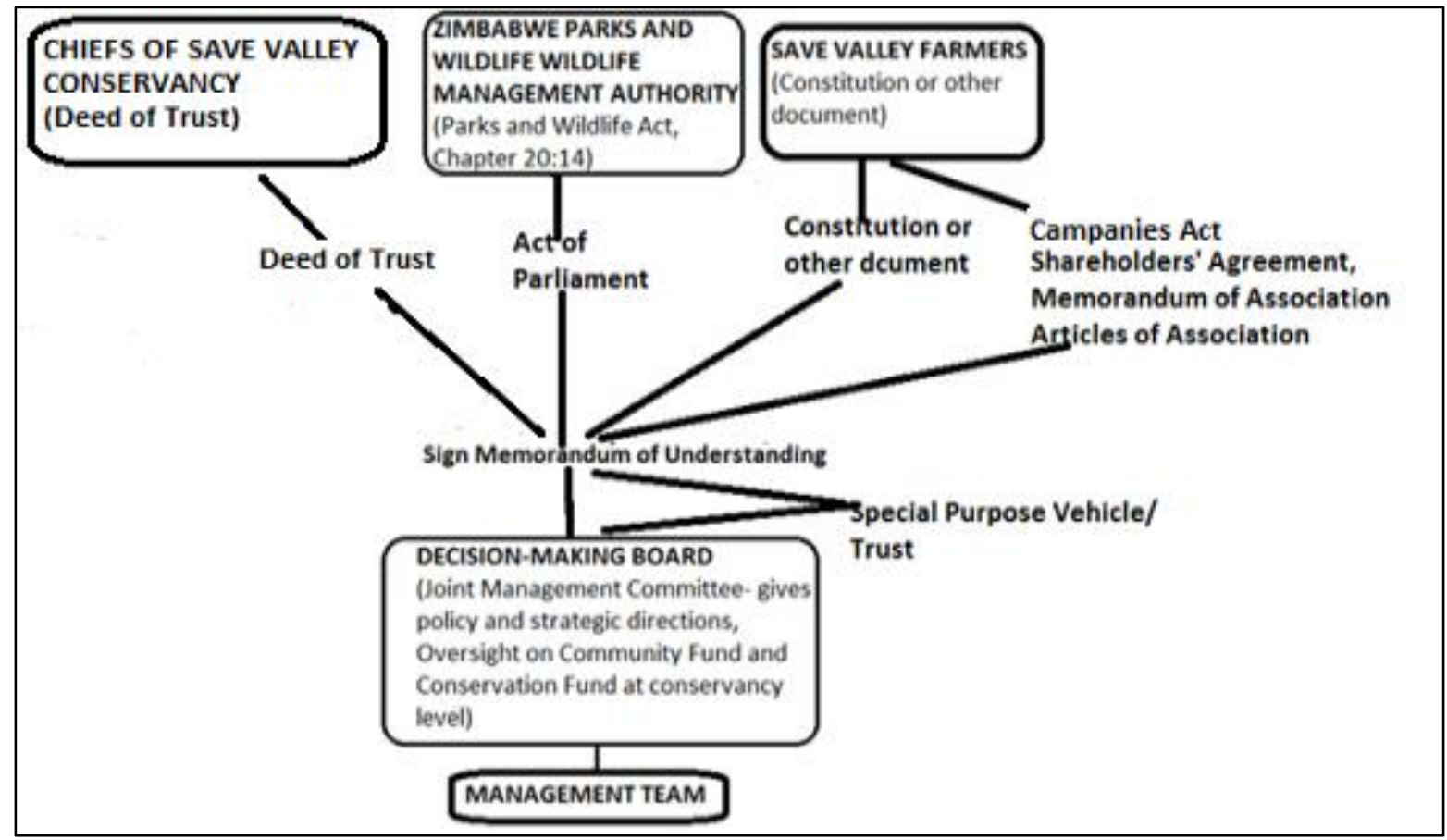

The MoA contained the provision for establishing a Joint Management Board comprised three (3) representatives of each of the three stakeholder groups (Local communities, new farmers, and former farmers) with voting rights and three (3) exofficio who should be two (2) representatives from ZPWMA and (1) technical advisor. The members shall agree on a Chairman from time to time.

Each farm was going to be managed like a company. New beneficiaries would be allocated $41 \%$, old beneficiaries $49 \%$ and local community $10 \%$ of the issued shares in the companies to be formed. The communities' $10 \%$ benefit shall be paid into a Community Share Ownership Scheme that shall be managed by the chiefs with assistance from ZPWMA and all other relevant Government Ministries and Departments. The new farmers would bring as their equity the land, the wildlife, and the diverse skills including business and legal, while the former farmers would contribute their historical investment in the form of infrastructure and expertise in the business. Local communities were not contributing anything to the project other than the local level political support.

Upon signature of the MOA, the parties should develop a Shareholding Agreement for their companies. Upon signature of this MOA new beneficiaries (farmers) will be allowed to provide at least two (2) representatives to base at each ranch and who will be accommodated as appropriate. The former farmers and two new farmers would take social responsibility seriously inter alia shareholding and future programmes. The chiefs if they wished they could be incorporated in the companies as individuals through their initiation while their communities benefit from the 10\% community share ownership trust. The parties would develop a proper and genuine benefit-sharing model that would be overseen by the Joint Management Board.

The constitution and founding documents of the company would state a certain percentage of revenue generated (based on business plan) meant 
for reinvestment in the operating costs of the conservancy through a conservation Management Fund; also state a certain percentage of revenue generated (based on the business plan) meant for Community Development Fund, i.e., for community development purposes. Revenue, after that, would be distributed to members through a Conservation Management Rebate Mechanism. Nevertheless, the partners did not agree on the shareholding and how to work together, as a result, implementation of the partnership was delayed.

\section{Governance from 2014 Onwards}

After finding that the potential partners had failed to work together, the Government resolved the following on the management of SVC in 2014;

- All farms covered by Bilateral Investments Promotion Protection Agreements (BIPPA) and privately acquired indigenous properties, Government parastatals (the Agricultural and Rural Development Authority) and Rural District Council-owned properties to remain in the hands of their former owners for administration,

- That the ZPWMA manages other gazetted properties in the SVC and works with communities using Community-based natural resources management programme in the country,
- Withdraw all twenty-five-year leases issued to groups of indigenous or new wildlife farmers in the SVC,

The resolutions instructed ZPWMA to start negotiating with local communities, the type of governance, business, and institutional arrangements for the management of some farms in the conservancies. The new farmers were removed from the project through government policy directives. The benefit-sharing model was agreed at 70:30 benefit-sharing gross income in favour of ZPWMA. The former farmers refused to renegotiate the Agreement and join the partnership and as a result, the project remained unimplemented.

\section{The Gudo Community Governance Arrangements}

Another public-community model involved the Gudo Community as a commercial business entity that won a hunting concession at an auction and paid its dues to the property holder, ZPWMA. The community formed and registered a Trust with a Board of Trustees that did business for the community, including signing Agreements with different business partners for hunting rights, hunting operations and funding (Figure 7). The community could decide how to use the revenue generated from its business. The Gudo community also intended to benefit from the first SVC model presented above.

Figure 7: Gudo community as a business entity and hunting concessionaire in 2016

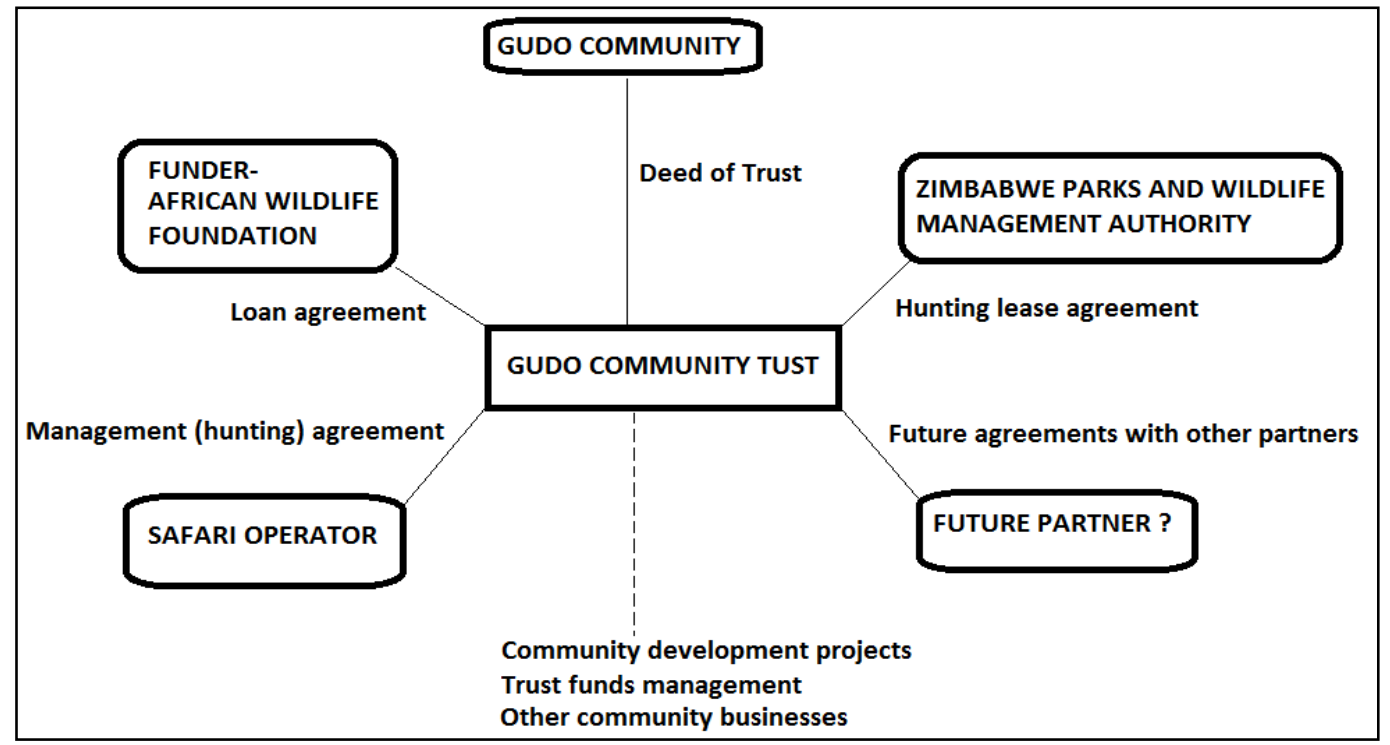

100 This work is licensed under a Creative Commons Attribution 4.0 International License. 
In the two SVC models given above, business and financial arrangements with communities, investment, and conservation risks had been allocated to ZPWMA and private farmers. The proposal to bring in former and indigenous farmers in the conservancy business aimed at improving the inclusivity of the business and financing model for the project (AWF, 2012).

\section{Factors Affecting the Governance Arrangements}

\section{Exclusionary Governance Arrangements}

Besides SVC, the other two projects had exclusionary governance against the local communities. Communities were not involved in decision-making and receiving any meaningful benefits from the projects.

\section{Land Claims and Invasions}

There were historical problems linked to past local community evictions from the land now occupied by the protected areas, exclusionary governance, and lack of community benefits. Local communities continued to press land claims from and invade the project areas and graze their livestock in the project areas, compromising the security of the areas. In SVC, some local communities were legally allocated pieces of land under the land reform programme.

\section{Inadequate Guidelines}

The lack of guiding documents such as a sectorspecific policy, legislation and stand operation procedures and manuals, and poorly negotiated MOU or MOAs created a governance vacuum. The absence of decision-making bodies, failure to fill strategic posts or Board posts with experienced and board members to make decisions, or delaying decision making by the public entity worsened governance problems. There were no clear partner consultation guidelines, communication lines, decision-making procedure, role and responsibility clarity and lack of transparency, giving room to the private partners to create parallel staff structures and multiple reporting lines in the early stages of GNP and MSA projects.

The partners had different business cultures with the public partner being slow and bureaucratic. For example, it took the Government over eight months to finalize the MSA partnership and four years for the GNP project. The SVC project was negotiated for 8 years and by April 2020 had not been fully implemented. The projects were negotiated at a high level and their governance types were not apparent to most of the participants from the start of the projects because of the poorly negotiated and communicated MOAs. The public entity wanted to control the partnership. Even in SVC, some traditional Chiefs were unclear on how they were going to participate in the project. As a result, all the partnerships were characterized by poor partner relations in their early stages.

\section{Politics and Policies}

In general, the technocrats running the projects were warry about the impact of politics, some policies and mismanagement of resources that might chase away investors and destroy the projects. The project started in a politically charged anti-white environment where political leaders accused all three partnerships of returning land to Europeans. Management was seized with the political connotations and perception of the projects for a while. For example, Government policy shifts presented SVC with many unique issues to resolve in the process of setting up PPCP. In the early 2000s, all the farms in SVC were designated by Government under the land reform program and became State property.

Although the Wildlife Based Land Reform Policy (WBLRP) provided for the former farm owners and new farmers to co-exist at the farm level, the farmers failed to do so on the farms. The new farmers were viewed as political appointees with limited financial and technical capacity to participate in the project being imposed by the Government on the former farmers. Chiefs strongly regarded the new farmers as part of their subjects who should work under traditional leadership. On the other hand, new farmers counter-accused the former farm owners of undermining the Government's wildlife indigenization programme by refusing to jointly develop a business plan since 2007 and stage-manging the signing of an agreement to work with local communities in 2000 because none of the people who signed the Agreement represented the communities and 
Chiefs. The new farmers further accused the former farm owners of influencing communities and chiefs to work against them in the project and of fronting a black person as Chairman of the conservancy.

Politics affected shareholding in the partnerships. GNP project did not involve shares, while in MSA, the shareholding was 50:50 and had no issues other than being arbitrary arrived at without reference to shareholder contributions to the project. In SVC, the partners disagreed on the proposed collaborative framework and shareholding of $49 \%$ for former farm owners, $41 \%$ for indigenous farmers and $10 \%$ of shares were for the communities. Each partner wanted more shares than the proposed and the Chiefs also demanded personal shares. Chiefs whose land covered the largest part of the conservancy and or whose people had not settled in the conservancy demanded the largest shareholding amongst the chiefs as compensation. The matter was not resolved until the end of this study.

There were legal battles between the former farmers and the Government. According to the new National Constitution and WBLRP, the settlement of new farmers in the conservancy was legal and empowering through the twenty-five-year leases. In 2012, the former farm owners of SVC took Government to the High Court seeking hunting quotas alleging ownership of SVC. Their case was dismissed on the following two points;

- The former owners of the land, which used to constitute SVC lost their rights to the said land to the State by operation of law during the land reform programme when their farms were designated (designated land becomes state property), and.

- The SVC Constitution automatically terminates the membership of a member who ceases to own property in the area; as such, the white farmers had no legal basis to represent in SVC.

The former farm owners continued to claim their investments in SVC and compensation for the investment hence entitled to be there. On the other side, chiefs and communities claimed that they had historical and customary rights to SVC as they used to live in the area before they were forcibly removed and relocated elsewhere in the early 1900s. There were further changes in Government Ministries and policy impacting the SVC partnerships. The reshuffling of five Cabinet Ministers, four Permanent Secretaries and four ZPWMA boards of directors from 2015 to 2020 slowed down the project development as the new policymakers needed time to study the SVC partnership. The government made further changes in February 2020 through a new piece of legislation, Statutory Instrument 62 of 2020 (CAP. 20:29) Land Commission (Gazetted Land) (Disposal in Lieu of Compensation) Regulations, 2020, which has a provision for citizens from countries that had BIPPA with Zimbabwe and indigenous persons whose farms were gazetted to either apply for compensation from the Government or repossess the farms.

\section{Project Monitoring, Auditing, and Evaluation}

The projects were not being monitored and evaluated for decision-makers to give strategies to run the areas. In both GNP and MSA, internal auditors and Auditor-General's office (external Government auditors) could not audit partnerships. International audits started work for both GNP and MSA in 2017.

\section{DISCUSSIONS}

\section{Governance Structures}

Partnership models do not fall in neat categories but lie on a continuum of possibilities (Baghai et al., 2018; Borinni-Feyerabend et al., 2013). It is not always easy to assign a governance type to a protected area because some protected areas combine features of several governance types and governance arrangements often change over time (Borrini-Feyerabend et al., 2013). Government agency has a central role to negotiate and advise in the continuum of decision-making considering sharing authority, responsibility, and accountability in governing protected areas. While it should be possible to determine the dominant governance system of a given protected area, different protected areas within the same governance type could be at different positions along the continuum, and for a given protected area, the position in the continuum could vary for different kinds of governance decisions (Borrini-Feyerabendet al., 2013). 
Three models of partnership for the management of protected areas in Africa fall between full state and full private control of the project and are; a) financial and technical support protected area management without formal decision making, b) co-management by all the partners, and c) thirdly delegated management authority (contract management) (Hatchwell, 2014; and Baghai et al., 2018). The initial financial arrangement governance for GNP and the JVC governance for MSA was not static as they morphed into delegated governance forms with time. The delegated models handed over the management of protected areas to either a notfor-profit or a for-profit special purpose vehicle (SPV) during the study. The delegated models had political problems because of the feeling of State disempowering and loss of sovereignty and legitimacy issues (Banghai et al., 2018).

Further, it implied that Government had failed to manage the protected area; foreigners had purchased the protected area from the government, and there would be security problems as law enforcement would be under non-state partners (Baghai et al., 2018). Co-management could have allowed the capacity building of both partners, but there is potential for the project to collapse if the other partner disengages, the project is vulnerable to political interference, there are inherent problems in the alignment of two structures of the partner entities, which usually leads to confusion over roles and responsibilities, heightened risk of conflict and misunderstanding and slower and more bureaucratic decision-making based on consensus over management matters (Baghai et al., 2018). The financial and or technical support model is flexible, empowering, but it is loose relying on personal relationships, mostly informal in decision making and prone to political interference (Baghai et al., 2018).

Strictly, there is no absolute delegated governance in nature as Government policies and legislation govern how partnerships operated (Bangai et al., 2018). There are challenges to achieving equitably managed protected areas, particularly in ensuring active participation in decision-making, transparent procedures, access to justice in conflicting situations, and the recognition of the rights and diversity of local people (Zafra-Calvo et al., 2019). The exclusionary protected area governance (exclusion of local communities) (Andrade \& Rhodes, 2012) was a poor governance practice that was bound to fail the partnerships. Local communities often left out (Muboko, 2011) should participate as equal partners in decision making to guarantee the success of the partnerships. Equitably manage protected areas is a governance issue (Convention on Biological Diversity, 2010; Pascual et al., 2014). The expectation is that governance types that enable genuine participation of communities will lead to a more equitable distribution of benefits and costs (i.e., social impacts) and thus make a more significant contribution to human wellbeing (Franks et al., 2018).

The lack of decision-making bodies and failure to fill strategic posts in GNP and MSA and to develop a voluntary governance arrangement SVC created a governance vacuum in the projects. On the other side, having both a decision-making body and management committee at the protected area level over-crowded the governance space resulting in a slow and bureaucratic decision-making process in MSA. The SPVs formed dealt with governance deficiencies in GNP and MSA. The Organization for Economic Cooperation and Development (OECD, 2012) advised on the necessity to establish a clear-cut and partner-resourced legitimate institutional arrangement. In GNP, the Trust had many advantages including appointing its trustees through the Partners of the project, the donor communities are amenable to work with trusts rather than private companies, a trust is not subject to paying taxes, and the partners define the business of the trust.

\section{Politics and Policies}

Policies strongly influence partnerships and are ever-changing therefore, partnerships keep on changing with the needs of humankind (Carnwell \& Carson, 2005). It means that certain parameters make a specific partnership either work or fail. Partnerships keep on morphing from one form to another and therefore, the results of this study are transient. For example, co-management models are profoundly impacted in the event of a breakdown in relations and are more exposed to political interference (Baghai et al., 2018). The challenge is to determine the types and amounts of ingredients 
(factors) that sustain a given version of partnership for the successful management of a given protected area, maximizing benefits while minimizing losses to man and biodiversity as time changes. Each partnership model is abstract and can be described by components of its framework. It means; therefore, the development of conservation partnership models is not a simple linear progression of events; because the trajectory can take any direction giving an $\mathrm{N}$-dimensional model of partnerships. For example, the initial SVC private-community partnership in 2000 collapsed and was resurrected as PPCP efforts in 2014.

\section{Land Claims}

Partners in the projects used different entitlements to lay land claims to the project areas. These ranged from historical and customarily rights to the land in local communities, a law in the public players and some private players, and investments made in the projects by other private layers. Land claims by local communities have been a product of previous historical evictions, lack of access to ritual sites for traditional ceremonies, lack of consultations, insignificant benefits, and their exclusion in the decision-making processes of the projects. The necessary governance reforms for the protected area also needed to recognize traditional and cultural sites in the project areas and develop governance types of the sacred sites formally attributed to the local ethnic indigenous people and nested within project shared governance.

\section{Misunderstanding and Mistrust}

The poor relations between the partners at the station level were a product of a lack of shared goals, partnership governance, interference and unilateral decision making by the shareholders, lack of transparency on the project funds accountability, and mistrust, the absence and or unclear policy or absence of sector-specific policies, legislation, and standard operations procedures, guidelines that set up and manage partnership projects, that define the roles and responsibility of the partners and absence of a project-wide stakeholder (local communities, employee, the general public) and shareholder consultation process. The government of Ireland (2003) advised taking on board the socio-economic and environmental concerns of those directly affected by the project along with the statutory rights and legitimate economic interests of the clients and other stakeholders. The public partner, through an Act of Parliament, is mandated to manage the parks and wildlife estate and wildlife in the country and felt that it should be in control of the projects. Baghai et al. (2018) advised that there is a need to align partners under the co-management model to reduce risks of conflict and misunderstanding between the partners and slowing of decision-making processes as there is a need for a consensus approach. The alignment of the partners streamlines their roles and responsibilities of which OECD (2012) said should be made clear and maintained to reduce conflicts.

An essential requirement of good corporate governance is the ability of the company to maintain independence from the government (Asian Development Bank, 2008). The public partner was both part-owner and regulator and could meddle in the project's business for various reasons. The partners' employees appointed as directors of JVC needed to be aware of the fiduciary duty to JVC and that their primary duty was to the company and not to the shareholder. Further, the public partner did not empower its representatives to make decisions. The institutional and governance vacuum resulted in the private partners being able to create parallel structures and lines of reporting from station to Ministry and controlled the project resources and their distribution. The structural defects and dysfunctionality created tension between the partners at the ground level and, as a result, negatively affected staff morale and the project at large (Matipano, 2020). Uncooperative working environments can lead to operational difficulties between partners (Klijn \& Teisman, 2003; McCann et al., 2014). An excellent partner business relationship requires creating and sustain a shared vision through consensus, for partners and key stakeholders to understand each other and to secure a consistent and coordinated leadership and as well as to communicate early and often on partnership matters (Corrigan et al., 2005). Unresolved disputes on shareholdings and the legality and ethics of imposing partners and their contribution to the project failed the SVC partnership. De la Torre and Rudolph (2015, p. 5) noted that failing to resolve disputes adequately was characteristic of flawed partnerships. 


\section{Monitoring and Evaluation}

In all the case studies, partners need to develop methods for ongoing auditing, monitoring, evaluating, and revising the aims, objectives, and performance of the partnership for the success of the project. LaFond and Brown (2003) advised on the need to monitor and evaluate the effectiveness of each partner's intervention through a wellstructured system of repeated surveys. At the beginning of each project, a baseline survey is necessary to set out indicators recording the ecological and socio-economic changes and the perception of the rights holders and stakeholders. The indicators are not static and are updated periodically (Breul \& Moravitz, 2007). Given that this is a new approach to conservation, the application of adaptive management, with a strong element of monitoring, is essential. The frequency of monitoring is often in the contract from an outcome basis. Performance and contract management functions should overlap to ensure continuity. Contract management ensures understanding and accomplishing the roles and responsibilities of each party in the project agreement. Performance management is a component of contract management, which is the day-to-day assessment of the service provided. The monitoring and control systems track the achievement of performance standards set out in the contract.

\section{Control of the Project Legal Form of the Partnership}

Lienert (2009) pointed that a partner has control of the partnership if it has the a) power condition (involving the majority voting interest, the power to appoint or remove members, majority vote and other specific indicators, e.g., veto powers on some issues like budget), and b) benefit condition (such as the power to dissolve, control over asset distribution or liabilities, the power to direct the partnership to cooperate with it to achieve certain benefits, and other benefits such as holding title to net assets). Control of the project should be through equity and preference shares and as captured in the Shareholders' Agreement or mutually agreed in the project documents. However, the Government of Ireland (2004) warned that excessive control should not be given to the minority shareholder by preference shares.

\section{CONCLUSION}

The protected area shared governance was not stable in the early stages of the projects because the concept of partnerships was new in Zimbabwe. That called for the need to develop guiding policy, legislation, and manuals and build capacity before implementing the partnerships. The inclusion of local communities is paramount in partnership management of protected areas in developing countries. There is a need to recognize traditional and cultural sites in the project areas, develop governance types of the sacred sites attributed to the local ethnic indigenous people and nested within project shared governance. However, care must be taken not to over-crowed the governance space of protected areas. Politics need to be kept at a minimum level in the partnerships. Governance CSFs developed are additional to those developed by others (Franks et al., 2018; Borrini-Feyerabend et al., 2013). Some critical success factors (CSFs) that ensure success in the shared governance of protected areas are; Providing supportive political will and guidance, Appropriate formal governance arrangements inclusive of all major stakeholders and rights holders, Developing and implementing stakeholder consultation guidelines, Effective risk management strategy, Local community participation as equal partners in decision making, Indigene local community at appropriate lowest level of governance of traditional leadership, and The practical project, contract and performance management.

\section{REFERENCES}

African Parks. (2011). Our parks: A business approach to the management of protected areas. http://www.african-parks.org/ downloaded 13 March 2012.

African Wildlife Foundation (AWF). (2012). Unleashing the potential of indigenized wildlife conservancies in Zimbabwe through community empowerment; Save Valley Conservancy pilot, September 2012. Pp 42.

Andrade, G. S., \& Rhodes, J. R. (2012). Protected areas and local communities: an inevitable 
partnership toward successful conservation strategies? Ecology and Society, 17(4).

Asian Development Bank. (2008). Public-Private Partnership Handbook. Asian Development Bank. http://www.apec.org.au/docs/adb\%20pub lic\%20private\%20partnership\%20handbook.pdf

Baghai, M., Miller, J. R., Blanken, L. J., Dublin, H. T., Fitzgerald, K. H., Gandiwa, P., ... \& Lindsey, P. (2018). Models for the collaborative management of Africa's protected areas. Biological Conservation, 218, 73-82.

Bauman, T., \& Smyth, D. (2007). Indigenous partnerships in protected area management in Australia: three case studies (pp. 95-114). Canberra: Australian Institute of Aboriginal and Torres Strait Islander Studies.

Becker, M. (2016). Expanding the use of partnership for national parks conservation. The Conservation Finance Network. https://www.conservationfinancenetwork.org/2 016/04/12/expanding-the-use-of-partnershipsfor-national-parks-conservation

Borrini-Feyerabend, G., Dudley, N., Jaeger, T., Lassen, B., Neema, P., Phillips, A., \& Sandwith, T. (2013). Governance of protected areas: from understanding to action. Best practice protected area guidelines series, (20).

Breul, J. D., \& Moravitz, C. (Eds.). (2007). Integrating performance and budgets: The budget office of tomorrow. Rowman \& Littlefield.

Carnwell, R., \& Carson, A. (2005). Understanding partnerships and collaboration. Effective practice in health and social care, 4-20.

Convention on Biological Diversity (CBD). (2010). A quick guide to the Aichi Biodiversity TargetsTarget 11: Protected areas increased and improved. Montreal, Canada. CBD.

Corrigan, B. M., Hambene, J., Hudnut III, W., Levitt, L. R., Stainback, J., Ward, R. \& Witenstein, N. (2005). Ten Elements of principles for Successful Public/Private Partnerships. Urban Land Institute, Washington DC, pp 42.
De la Torre, A., \& Rudolph, H. (2014). The Seven Sins of Flawed Public-Private Partnerships. The World Bank. http://documents.worldbank.org/c urated/en/191831468186273847/The-sevensins-of-flawed-public-private-partnerships.

Emerton, L., \& Mfunda, I. (1999). Making wildlife economically viable for communities living around the Western Serengeti, Tanzania. International Institute for Environment and Development, Biodiversity and Livelihoods Group.

Franks, P., Booker, F., \& Roe, D. (2018). Understanding and assessing equity in protected area conservation: a matter of governance, rights, social impacts and human wellbeing. International Institute for Environment and Development.

Government of Ireland. (2003). Policy Framework for Public-private Partnership (PPP) in Ireland. Project Implementation in the Local Government Sector, November 2003, pp 55.

Government of Ireland. (2004). Public-private Partnerships in the Local government sector: Guidance on PPP Joint Venture Companies: Guidance on the adoption of a Joint Venture Company approach for a Public-private Partnership in Ireland: Technical Note: 4 Department of Environment, Heritage and Local Government: pp 81Government of Zimbabwe. (1996). The Parks and Wildlife Act. Chapter 20:14. Government Printers.

Graham, J., Amos, B., \& Plumptre, T. W. (2003). Governance principles for protected areas in the 21st century (pp. 1-2). Ottawa: Institute on Governance, Governance Principles for Protected Areas.

Hatchwell, M. (2014). Public-private partnerships as a management option for protected areas. Animal Conservation, 17(1), 3-4.

Klijn, E. H., \& Teisman, G. R. (2003). Institutional and strategic barriers to public-private partnership: An analysis of Dutch cases. Public money and management, 23(3), 137-146.

106 | This work is licensed under a Creative Commons Attribution 4.0 International License. 
LaFond, A., \& Brown, L. (2003). A guide to monitoring and evaluation of capacity building interventions in the health sector in developing countries.

Lavrakas, P. J. (2008). Encyclopaedia of survey research methods. Sage publications.

Lienert, I. (2009). Where does the public sector end and the private sector begin?.

McCann, S., Aranda-Mena, G., \& Edwards, P. J. (2014). Managing partnership relations and contractual performance in the operating phase of public private partnership: Interview findings. International Public Management Review, 15(2), 111-132.

McNeely, J. A. (1988). Economics and biological diversity: developing and using economic incentives to conserve biological resources. IUCN.

Miles, M. B., \& Huberman, A. M. (1994). Qualitative data analysis: An expanded sourcebook. Sage.

Muboko, N. (2011). Conflict and sustainable development: the case of the Great Limpopo Transfrontier Park (GLTP); Southern Africa (Doctoral dissertation, D. Phil. thesis. Nelson Mandela Metropolitan University, Port Elizabeth).

Organization for Economic Cooperation and Development (OECD). (2012). Recommendations of the Council on Elements of principles for public governance of publicprivate partnerships. Pp. 28.

Pascual, U., Phelps, J., Garmendia, E., Brown, K., Corbera, E., Martin, A., ... \& Muradian, R. (2014). Social equity matters in payments for ecosystem services. Bioscience, 64(11), 10271036.

Reid, H., Fig, D., Magome, H., \& Leader-Williams, N. (2004). Co-management of contractual national parks in South Africa: Lessons from Australia. Conservation and Society, 377-409.

Saunders, M. (2014). Research Methods for Business Students, 6th ed.Saunders, M., Lewis,
P. \& Thornhill, A. (2012). Research Methods for Business Students, $6^{\text {th }}$ Edition. McGraw, London, Britain.

Stolton, S., \& Dudley, N. (2014). Partnerships for protection: new strategies for planning and management for protected areas. Routledge.

Tie, C. Y.; Birks, M. \& Francis, K. (2019). Grounded theory research: A design framework for novice researchers. SAGE Open Medicine, 7, $1-8$.

Yang, Q. (2011). Partnership for facilitating sustainable protected area management: a case study of Jiuzhaigou National Park in southwestern China. Master's Thesis. Massey University.

Wolmer, W., Chaumba, J., \& Scoones, I. (2004). Wildlife management and land reform in southeastern Zimbabwe: a compatible pairing or a contradiction in terms?, Geoforum, 35(1), 87-98.

Worboys, G. L., Lockwood, M., Kothari, A., Feary, S., \& Pulsford, I. (Eds.). (2015). Protected area governance and management. Anu Press.

Zafra-Calvo, N., Garmendia, E., Pascual, U., Palomo, I., Gross-Camp, N., Brockington, D., ... \& Burgess, N. D. (2019). Progress toward equitably managed protected areas in Aichi target 11: a global survey. BioScience, 69(3), 191-197.

$107 \mid$ This work is licensed under a Creative Commons Attribution 4.0 International License. 